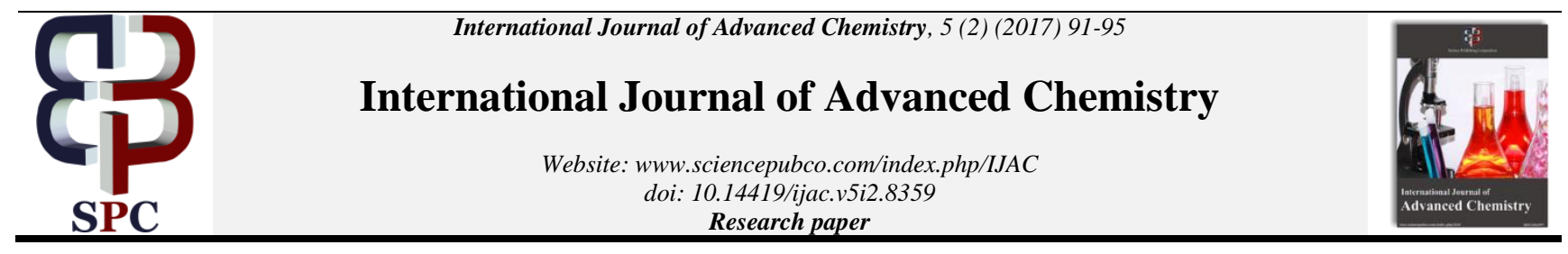

\title{
Synthesis, structural characterization and comparison of experimental and theoretical results by DFT level of molecular structures of 1,2,3-triazoles derived from 5-chloroisatin
}

\author{
Zineb. Tribak ${ }^{1 *}$, Mohammed. Khalid. Skalli ${ }^{1}$, Omar. Senhaji ${ }^{2}$, Youssef. Kandri. Rodi ${ }^{1}$ \\ ${ }^{1}$ Laboratory of Applied Chemistry, Sidi Mohamed Ben Abdellah University, Faculty of Sciences and Technology of Fez, Morocco \\ ${ }^{2}$ Laboratory of Applied Physical Chemistry, MoulayIsmaïl University, Faculty of Sciences and Technology of Errachidia, Morocco \\ *Corresponding author E-mail: tribak.zineb@gmail.com
}

\begin{abstract}
This work deals about the synthesis, NMR characterization and the density functional method (B3LYP) with the 6-31G basis set of 1, 3 -dipolar cycloaddition reactions between the two azides as dipoles and propargylchloroisatin as dipolarophile. Furthermore, DFT calculations were used to study the nucleophile-electrophile interactions of the azides and dipolarophile and also the stability between the regioisomers comparing their energy. Our calculations are in a good agreement with the experimental findings.
\end{abstract}

Keywords:5-Chloro-1-(Prop-2-Yn-1-Yl) Indoline-2; 3-Dione; Dipolarophile; 1,3-Dipolar Cycloaddition; Theoretical Study; DFT.

\section{Introduction}

The construction of five-membered rings with heteroatoms via 1.3-dipolar cycloaddition is the most attractive strategy for preparing a frequently natural product structure because of their ability to create regioselectivity manner cyclic motifs in organic molecules (Tribak et al. 2017, Foss et al.2009). A great amount of works has been focused to methods for the synthesis of an accessible three-atom component using these reactions. The azides as dipoles are a class of powerful reagents, which react readily with various alkynes to afford triazoles rings, which are moieties present in antiallergic, antibacterial, antifungal, antivirial and analgestic drugs, however, its 1, 2, 4-isomer is used as a drug structure's component much more frequently. In addition, they can also protect plants against various environmental stresses (Fowler et al. 1992, Prato et al. 1997, Moriyama et al. 1998, Wannassi et al. 2012, Kumar Kaushik et al. 2013, Krug et al. 2008).

In the literature, we can found a considerable amount of theoretical and experimental works which have been devoted to the study of the mechanisms and selectivity of cycloaddition reactions of dipole derivatives using the quantitative transition state theory. In recent years, density functional theory (DFT) has been extensively used in theoretical modeling. The development of better exchange-correlation functional has made it possible to calculate many molecular properties with comparable accuracies to traditionally cycloaddition methods, with more favorable computational costs (Tribak et al. 2017, Tribak et al. 2016, Tribak et al. 2017, Rauk et al. 2001, Nguen et al. 2003).

In this study, we synthesized new 1.2.3-triazoles derivatives of 5Chloroisatin and aimed to investigate the energetic and structural properties of 1,2,3-triazole compound, using density functional theory calculations, at the B3LYP/6-31G level of theory used the program Gaussian 09W and compared with experimental results obtained from the synthesis by 1.3-dipolar cycloaddition (Geerlings et al. 2003, Senhaji et al. 2011, Kolb et al. 2004, Brase et al. 2005).

\section{Results and discussion}

\subsection{Synthesis of dipolarophile 2}

In order to synthesize new dipolarophile derived from 5Chloroisatin, which can be used as a precursor in the 1,3-dipolar cycloaddition reactions, we have chosen to react 5-Chloroisatin at room temperature with 3-bromo prop-1-yen in the conditions of liquid-solid phase transfer catalysis in DMF as solvent, using $\mathrm{K}_{2} \mathrm{CO}_{3}$ as the base and BTBA as a catalyst, to prepare the compound 5-chloro-1-(prop-2-yn-1-yl)indoline-2,3-dione (Tribak et al. 2016).<smiles>C#CCN1C(=O)C(=O)c2cc(Cl)ccc21</smiles>

Scheme 1

\subsection{Condensation with azides}

Among the numerous methods of preparing the pentagonal heterocyclics, the 1,3-dipolar cycloaddition reactions constitute an elegant synthesis process. The bibliography offers many examples of 1, 3-dipolar cycloaddition reactions. We are particularly interested here in the cycloaddition reaction of azides with alkynes, making 
it possible to obtain a wide variety of five-membered heterocyclics in a rapid, reproducible and quantitative manner, via hetero-atomic bonds. The Huisgen reaction proper is an addition between a true alkyne and an azide to form a triazole ring, the conventional conditions of this reaction require high temperatures, long reaction times and lead to a mixture of two disubstituted isomer triazoles 1 , 4 and 1.5 .

In our case, the action of the two azides 1-azidodecane (a) and 1azaspirodecanedione (b) on 5-chloro-1-(prop-2-ynyl)indoline-2,3dione as a dipolarities under reflux of ethanol for days led to the formation of the regioisomers resulting from the attack of the nucleophilic nitrogen of the dipoles on the sp3 carbon more electrophilic of the dipolarities (Huisgen, 1984).

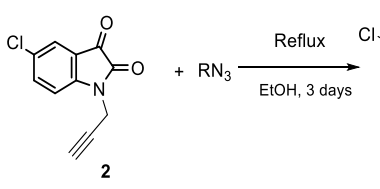

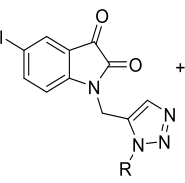

3:R $=\mathrm{C}_{10} \mathrm{H}_{21} ; 19 \%$ $5: R=\mathrm{C}_{12} \mathrm{H}_{25} ; 18 \%$
Scheme 2 b:R $=\mathrm{C}_{12} \mathrm{H}_{25}$

From the values of the yields experimentally obtained, it can be noted that the yield $(71 \%)$ of regioisomer 4 was better than the yield $(19 \%)$ of regioisomer 3 , the same conclusion was observed for the other regioisomers, it is clear that the yield (70\%) of compound 6 is bigger than the yield (18\%) of compound 5 .

\section{Theoretical studies}

\subsection{DFT study of compounds}

DFT (density functional theory) methods were used in this study These methods have become very popular in recent years because they can reach exactitude similar to other methods in less time and less expensive from the computational point of view. In agreement with the DFT results, energy of the fundamental state of a polyelectronic system can be expressed through the total electronic density. The calculations of geometrical parameters were performed using the Gaussian 09W program package and B3LYP (Becke's Three Parameter Hybrid Functional using the LYP Correlation Functional) approach in conjunction with the 6-31G basis set to understand, describe and identify the most reactive sites of dipolarities and dipole a and b (Hiberty 2004, Houk et al. 1973).

The reaction behavior can be explained using the orbital interactions of the load analysis (hard-hard reaction) or by presenting the local properties. It is generally accepted that the regiochemistry of the concerted 1,3-dipolar cycloaddition is controlled by the interactions of the boundary orbitals. In our case and in agreement with the analysis of FMO boundary molecular orbitals, the HOMO azide/LUMO-dipolarophile and LUMO-azide/HOMOdipolarophile energy differences are represented in table1 (Tribak et al. 2016, Fukui 1974).

Table1: Difference's Energy Possible between HOMO/LUMO Combinations of Azides and Dipolarophile

\begin{tabular}{lll}
\hline & |HOMO azide - LUMO alkyne & |HOMO alkyne -LUMO azide $\mid$ \\
\hline $\mathrm{a}$ & $3.522 \mathrm{eV}$ & $5.702 \mathrm{eV}$ \\
$\mathrm{b}$ & $3.564 \mathrm{eV}$ & $5.680 \mathrm{eV}$ \\
\hline
\end{tabular}

These results suggest that the reaction between the both azides and the dipolarophile is controlled by HOMO azide - LUMO dipolarophile, that represent by the small value for each azide. electron affinity $\left(\mathrm{EA}=-\mathrm{E}_{\mathrm{LUMO}}\right)$, ionization potential $\left(\mathrm{IP}=-\mathrm{E}_{\text {HOMO }}\right)$, electronegativity $\left(\chi=\frac{I P+E A}{2}\right)$, global hardness $\left(\eta=\frac{\text { IP-EA }}{2}\right)$, softness $\left(S=\frac{1}{\eta}\right)$, the overall electrophicity $(\omega)$, the electrophilicity condensed functions of Fukui $f_{k}$, the relative electrophilicity indices $\left(\mathrm{S}^{+}{ }_{\mathrm{k}} / \mathrm{S}_{\mathrm{k}}{ }_{\mathrm{k}}\right)$ and nucleophilicity indices $\left(\mathrm{S}_{\mathrm{k}} / \mathrm{S}^{+} \mathrm{k}\right)$ for dipolarophile 2 and dipoles $\mathrm{a}$ and $\mathrm{b}$ were presented in the tables 2, 3 and 4 (Weinberg et al. 2013).

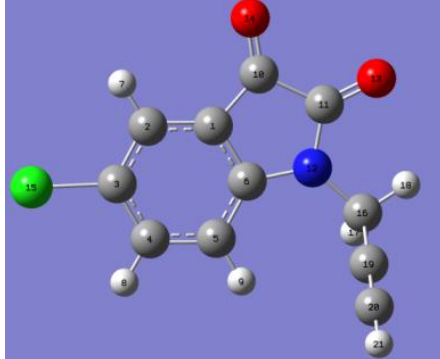

Fig. 1: Optimized Geometry of the Dipolarophile 2.

(a)

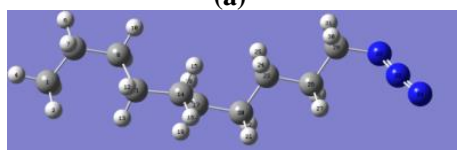

(b)

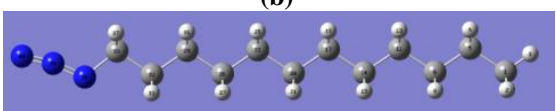

Fig. 2: Optimized Geometries of Dipoles a and b.

Table2: Ionization Potential (PI), Electronic Affinities (EA) and KohnSham Orbital Values for HOMO and LUMO in eV (Units)

\begin{tabular}{lllll}
\hline Molecules & HOMO & LUMO & EA & PI \\
\hline 2 & -6.7608 & -3.2462 & 3.2462 & 6.7608 \\
a & -6.7684 & -1.0587 & 1.0587 & 6.7684 \\
b & -6.8111 & -1.0802 & 1.0802 & 6.8111 \\
\hline
\end{tabular}

In a limited representation of the difference for these the calculations of these indices, $\mu, \eta$ and $\mathrm{S}$ can be evaluated from electron affinity (EA) and ionization potential (PI). Indeed, if one sees the difference of the chemical potential between the dipolarophile 2 and the azides, one can determine the direction of the transfer of charge (Pal et al. 2000, Mendez et al. 1994, Gazquez et al. 1994, Mendez et al. 1998, Domingo et al. 2004).

The result $\left(\left(\mu_{\mathrm{a}, \mathrm{b}}-\mu_{2}\right)\right.$ (table 3$)$ indicates that the net charge transfer will occur from azide ( $\mathrm{a}$ and $\mathrm{b}$ ) to the dipolarophile 2 in the case of all the reactions carried out, which implies that the azides act as nucleophiles. The same conclusion is made by considering the values $\omega$ of the overall electrophilicity, the largest value corresponds to the most electrophilic one which implies that the dipolarophile acts as an electrophile.

Table 3: Values In eV of Hardness $\eta$, Electronic Chemical Potential $\mu$, The Index of Electrophilicity $\omega$ and the Result $\Delta \mu$ of Compounds 2 and a-b

\begin{tabular}{lllllll}
\hline & $\boldsymbol{\chi}$ & $\eta$ & $\mathrm{S}$ & $\omega$ & $\mu$ & $\Delta \mu$ \\
\hline 2 & 5.0035 & 1.7572 & 0.5690 & 7.1233 & -5.0035 & - \\
$\mathrm{a}$ & 3.9136 & 2.8548 & 0.3502 & 2.6825 & -3.9136 & 1.0899 \\
$\mathrm{~b}$ & 3.9457 & 2.8654 & 0.3489 & 2.7166 & -3.9457 & 1.0578 \\
\hline
\end{tabular}

This reciprocal action corresponds to a reaction in which the electrophile-the dipolarophile reacts with the azide-the nucleophile. From a local point of view, the relative electrophilicity indexes $\left(\mathrm{S}^{+}{ }_{\mathrm{k}} / \mathrm{S}_{\mathrm{k}}^{-}\right)$and nucleophilicity $\left(\mathrm{S}_{\mathrm{k}}{ }_{\mathrm{k}} / \mathrm{S}^{+}{ }_{\mathrm{k}}\right)$ describe the electrophilicity of an atomic center compared with its own nucleophilicity (Roy et al. 1998, Roy et al. 1998, Pilepicet al. 2001, Al Houariet al. 2001). The site with the largest ratio $\left(\mathrm{S}^{+}{ }_{\mathrm{k}} / \mathrm{S}_{\mathrm{k}}{ }_{\mathrm{k}}\right)$ is the most likely site for a nucleophilic attack and the one with the largest $\left(\mathrm{S}_{\mathrm{k}}^{-} / \mathrm{S}^{+} \mathrm{k}\right)$, most likely to interact with an electrophile

Table 4: Relative Indices of Electrophilicity, Nucleophilicity (In eV) and Values of the Condensed Function of Fukui $f_{k}$ for the Junction Atoms for 2 and $\mathrm{a}$ and $\mathrm{b}$

\begin{tabular}{|c|c|c|c|c|c|}
\hline & Atoms & $\mathrm{f}_{\mathrm{k}}^{+}$ & $f_{k}^{2}$ & $\mathrm{~S}_{\mathrm{k}}^{+} / \mathrm{S}_{\mathrm{k}}^{-}$ & $\mathrm{S}_{\mathrm{k}}^{-} / \mathrm{S}^{+}{ }_{\mathrm{k}}$ \\
\hline \multirow{2}{*}{2} & C19 & -0.046 & -0.032 & 1.439 & 0.694 \\
\hline & $\mathrm{C} 20$ & 0.111 & 0.102 & 1.091 & 0.915 \\
\hline \multirow[b]{2}{*}{$\mathrm{a}$} & N32 & 0.162 & 0.180 & 0.899 & 1.111 \\
\hline & N34 & 0.200 & 0.228 & 0.875 & 1.142 \\
\hline \multirow{2}{*}{ b } & N38 & 0.149 & 0.162 & 0.921 & 1.084 \\
\hline & $\mathrm{N} 40$ & 0.162 & 0.230 & 0.702 & 1.423 \\
\hline
\end{tabular}


The carbon atom of the dipolarophile (C19) has a better $\mathrm{S}^{+} / \mathrm{S}^{-}{ }_{\mathrm{k}}$ ratio and can therefore be considered as the site most susceptible to nucleophilic attack. If we consider the azides, the $\mathrm{S}_{\mathrm{k}} / \mathrm{S}^{+}{ }_{\mathrm{k}}$ ratios (Table 4) suggest that the N34 and N40 nitrogens are the most reactive nucleophilic sites, which is in agreement with the experimental results. It would be important to consider that the reaction is not necessarily controlled orbitally.

The theoretical studies have been carried out and the natural loads have been calculated in order to understand the regiochemistry of the cycloadditions of the azides with the dipolarophile (Tribak et al. 2016,Tribak et al. 2016).

During this reaction, the majority isomers formed were explained by the reaction between the most negative side of the 1,3-dipole with the least negatively charged carbon of the triple bond.

The theoretical study is in perfect agreement with the regiochemistry obtained during the cycloaddition reaction.

\subsection{Stability study of cycloadducts 3,4 and 5,6}

The next step is to study the stability of compounds 3,4 and 5, 6 according to their energies, using the quantum chemistry calculation DFT/B3LYP/6-31G. The following figures 3 and 4 show their optimized structures.
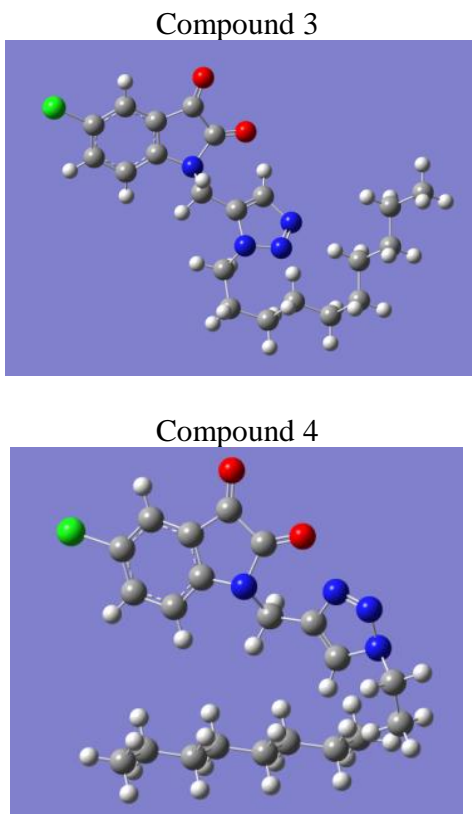

Fig. 3: The Obtained Molecular Structures 3 and 4 by DFT / B3LYP / 6 $31 \mathrm{G}$.

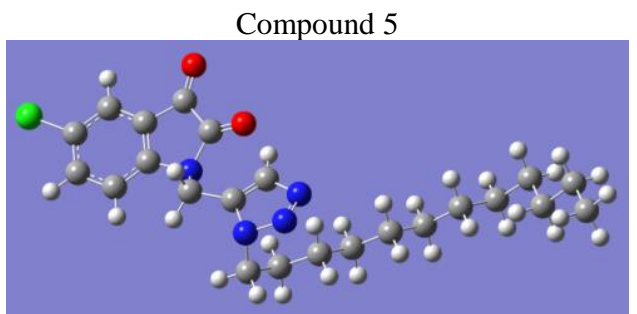

Compound 6

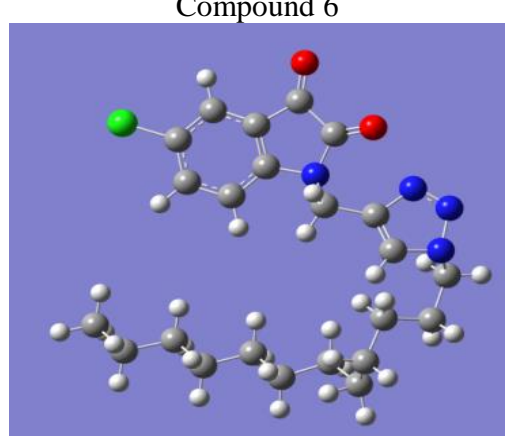

Fig. 4: The Obtained Molecular Structures 5 and 6 by DFT / B3LYP / 6 $31 \mathrm{G}$.
It can be seen that the regioisomer obtained theorical 4 is more stable than the isomer 3 of an energy gap of $5.83 \mathrm{Kcal} / \mathrm{mol}$, so the same thing is observed for the others regioisomers, it is seen that the regioisomer 6 is more stable than the isomer 5 of an energy gap of $5.15 \mathrm{Kcal} / \mathrm{mol}$. This is in agreement with the experimental results by computing the yields of the isomers.

\section{Experimental part}

\subsection{Generality}

Melting points were determined by a capillary apparatus: fine control Electrothermal capillary, and also by the kofler bench apparatus. NMR spectra were measured using a Brucker AC 300 at $300 \mathrm{MHz}\left({ }^{1} \mathrm{H}\right)$ and $75 \mathrm{MHz}\left({ }^{13} \mathrm{C}\right)$. All NMR spectra were recorded at room temperature in $\mathrm{CDCl}_{3}$ unless otherwise noted and chemical shifts ( $\delta$ in $\mathrm{ppm}$ ) were referenced to tetramethylsilane (TMS). Thin layer chromatography (TLC) was carried out on aluminum-coated silica gel coated Merck plates revealed by a U.V. The column chromatographies were carried out on 60 Merck silica gel (230-400 mesh).

\subsection{Synthesis of dipolarophile}

\subsubsection{General method for obtaining the dipolarophile}

5-Chloro-1H-indole-2,3-dione $0.2 \mathrm{~g}(1,1 \mathrm{mmol})$ is solubilized in 15 $\mathrm{mL}$ of N-N-dimethylformamide (DMF), $(0.23 \mathrm{~g}, 1.16 \mathrm{mmol})$ of potassium carbonate $(0.035 \mathrm{~g}, 0.10 \mathrm{mmol})$ of BTBA (tetra-nbutylammonium) are added with stirring at room temperature, thereafter 1.2 equivalents of 3-bromoprop-1-yne are slowly added, the mixture is allowed to stand for 48 hours. The product was obtained in $88 \%$ yield after column purification with an eluent (ethyl acetate/ hexane).

2: 5-chloro-1-(prop-2-ynyl) indoline-2,3-dione:

Yield: $88 \%$; mp: $166-170^{\circ} \mathrm{C} ; \mathrm{R}_{\mathrm{f}}=0.78(\mathrm{EtOH} / \mathrm{Hex}, 2: 1) .{ }^{1} \mathrm{H}$ NMR $\left(\mathrm{CDCl}_{3}\right) \delta$ ppm 7.57-7.62 (m, 2H, $\left.\mathrm{H}_{\mathrm{Ar}}\right) ; 7.12\left(\mathrm{~d}, \mathrm{H}, \mathrm{H}_{\mathrm{Ar}},{ }^{3} \mathrm{~J}_{\mathrm{H}-\mathrm{H}}\right.$ $=6 \mathrm{~Hz}) ; 4.54\left(\mathrm{~s}, 2 \mathrm{H}, \mathrm{CH}_{2}\right) ; 2.34\left(\mathrm{t}, \mathrm{H},{ }^{4} \mathrm{~J}_{\mathrm{H}-\mathrm{H}}=3 \mathrm{~Hz}\right),{ }^{13} \mathrm{C} \mathrm{NMR}$ $\left(\mathrm{CDCl}_{3}\right) \delta \mathrm{ppm}: 181.55(\mathrm{C}=\mathrm{O}) ; 156.60(\mathrm{~N}-\mathrm{C}=\mathrm{O}) ; 147.87,130.07$, $118.50(\mathrm{Cq}) ; 137.80,125.24,112.75\left(\mathrm{CH}_{\mathrm{Ar}}\right) ; 73.72(\mathrm{C} \equiv \mathrm{C}) ; 71.21$ $(\mathrm{CH}) ; 29.59\left(\mathrm{CH}_{2}\right)$

\subsubsection{General method for obtaining 1, 2, 3-triazoles}

$0.2 \mathrm{~g}$ of 5-chloro-1- (prop-2-ynyl) -indoline-2,3-dione and 1.2 equivalent of azides in ethanol are dissolved in a flask. The mixture is stirred under reflux for 3 days, the reaction is followed by TLC; the reaction crude is purified by chromatography on a silica gel column (ethyl acetate/Hexane (5/1)). The reaction leads to the formation of two separable regioisomers.

3: 5-chloro-1-((3-decyl-3H-1,2,3-triazol-4-yl)methyl)indoline-2,3dione:

Yield: $19 \%$; $\mathrm{mp}: \quad 130-135^{\circ} \mathrm{C} ; \quad \mathrm{R}_{\mathrm{f}}=0.55 .{ }^{1} \mathrm{H}$ NMR $\quad\left(\mathrm{CDCl}_{3}\right.$ $300 \mathrm{MHz}) \delta$ ppm $7.56\left(\mathrm{~m}, \mathrm{H}, \mathrm{H}_{\mathrm{Ar}}\right) ; 7.53-7.54\left(\mathrm{~m}, 2 \mathrm{H}, \mathrm{H}_{\mathrm{Ar}}\right) ; 7.33(\mathrm{~d}$, $\left.\mathrm{H}, \mathrm{H}_{\mathrm{Ar}},{ }^{4} \mathrm{~J}_{\mathrm{H}-\mathrm{H}}=3 \mathrm{~Hz}\right) ; 4.99\left(\mathrm{~s}, 2 \mathrm{H}, \mathrm{CH}_{2}\right) ; 4.29\left(\mathrm{t}, 2 \mathrm{H}, \mathrm{CH}_{2},{ }^{3} \mathrm{~J}_{\mathrm{H}-}\right.$ $\mathrm{H}=9 \mathrm{~Hz}) ; 1.82-1.87\left(\mathrm{~m}, 2 \mathrm{H}, \mathrm{CH}_{2}\right) ; 1.22\left(\mathrm{~m}, 14 \mathrm{H}, \mathrm{CH}_{2}\right), 0.86(\mathrm{t}, 3 \mathrm{H}$ $\left.\mathrm{CH}_{3},{ }^{3} \mathrm{~J}_{\mathrm{H}-\mathrm{H}}=6 \mathrm{~Hz}\right) .{ }^{13} \mathrm{C} \quad \mathrm{NMR}\left(\mathrm{CDCl}_{3} ; 75 \mathrm{MHz}\right) \delta p p m: 183.85$ $(\mathrm{C}=\mathrm{O}) ; 165.19(\mathrm{~N}-\mathrm{C}=\mathrm{O}) ; 147.60,144.20,130.63,111.98(\mathrm{Cq})$; 135.72, 130.42, $123.43\left(\mathrm{CH}_{\mathrm{Ar}}\right) 133.82(\mathrm{CH}) ; 53.67,45.41,33.11$, 29.93, 28.87, 27.39, $23.14\left(\mathrm{CH}_{2}\right) ; 16.78\left(\mathrm{CH}_{3}\right)$.

4:5-chloro-1-((1-decyl-1H-1,2,3-triazol-4 yl)methyl)indoline-2,3dione:

Yield: $71 \%$; mp: $130-135^{\circ} \mathrm{C} ; \quad \mathrm{R}_{\mathrm{f}}=0.55 .{ }^{1} \mathrm{H}$ NMR $\left(\mathrm{CDCl}_{3}\right.$ $300 \mathrm{MHz}) \delta \mathrm{ppm} 7.53\left(\mathrm{~m}, \mathrm{H}, \mathrm{H}_{\mathrm{Ar}}\right) ; 7.49-7.51\left(\mathrm{~m}, 2 \mathrm{H}, \mathrm{H}_{\mathrm{Ar}}\right) ; 7.28(\mathrm{~d}$, $\left.\mathrm{H}, \mathrm{H}_{\mathrm{Ar}},{ }^{4} \mathrm{~J}_{\mathrm{H}-\mathrm{H}}=3 \mathrm{~Hz}\right) ; 4.96\left(\mathrm{~m}, 2 \mathrm{H}, \mathrm{CH}_{2}\right) ; 4.26\left(\mathrm{t}, 2 \mathrm{H}, \mathrm{CH}_{2},{ }^{3} \mathrm{~J}_{\mathrm{H}-\mathrm{H}}\right.$ $=9 \mathrm{~Hz}) ; 1.80-1.84\left(\mathrm{~m}, 2 \mathrm{H}, \mathrm{CH}_{2}\right) ; 1.19\left(\mathrm{~m}, 14 \mathrm{H}, \mathrm{CH}_{2}\right), 0.81(\mathrm{t}, 3 \mathrm{H}$, $\left.\mathrm{CH}_{3},{ }^{3} \mathrm{~J}_{\mathrm{H}-\mathrm{H}}=6 \mathrm{~Hz}\right) .{ }^{13} \mathrm{C} \mathrm{NMR}\left(\mathrm{CDCl}_{3} ; 75 \mathrm{MHz}\right) \delta p p m: 183.54$ $(\mathrm{C}=\mathrm{O}) ; 164.89(\mathrm{~N}-\mathrm{C}=\mathrm{O}) ; 147.29,143.90,130.33,111.67(\mathrm{Cq})$; $135.42,130.12,124.82\left(\mathrm{CH}_{\mathrm{Ar}}\right) 123.12(\mathrm{CH}) ; 53.37,45.10,32.81$, 29.62, 28.57, 27.08, $22.84\left(\mathrm{CH}_{2}\right) 16.48\left(\mathrm{CH}_{3}\right)$ 
5:5-chloro-1-((3-dodecyl-3H-1,2,3-triazol-4-yl)methyl)indoline2,3-dione:

Yield: $18 \%$; mp: $135-138^{\circ} \mathrm{C} ; \quad \mathrm{R}_{\mathrm{f}}=0.55 . \quad{ }^{1} \mathrm{H} \quad \mathrm{NMR} \quad\left(\mathrm{CDCl}_{3}\right.$ $300 \mathrm{MHz}) \delta p p m$ 7.56(m, H, $\left.\mathrm{H}_{\mathrm{Ar}}\right) ; 7.51-7.53\left(\mathrm{~m}, 2 \mathrm{H}, \mathrm{H}_{\mathrm{Ar}}\right) ; 7.30(\mathrm{~d}$, $\left.\mathrm{H}, \mathrm{H}_{\mathrm{Ar},},{ }^{4} \mathrm{~J}_{\mathrm{H}-\mathrm{H}}=3 \mathrm{~Hz}\right) ; 4.98\left(\mathrm{~s}, 2 \mathrm{H}, \mathrm{CH}_{2}\right) ; 4.30\left(\mathrm{t}, 2 \mathrm{H}, \mathrm{CH}_{2},{ }^{4} \mathrm{~J}_{\mathrm{H}-\mathrm{H}}\right.$ $=3 \mathrm{~Hz}) ; 1.83\left(\mathrm{t}, 2 \mathrm{H}, \mathrm{CH}_{2},{ }^{3} \mathrm{~J}_{\mathrm{H}-\mathrm{H}}=9 \mathrm{~Hz}\right) ; 1.21\left(\mathrm{~m}, 10 \mathrm{H}, \mathrm{CH}_{2}\right) ; 0.85(\mathrm{t}$, $\left.3 \mathrm{H}, \mathrm{CH}_{3},{ }^{3} \mathrm{~J}_{\mathrm{H}-\mathrm{H}}=6 \mathrm{~Hz}\right) .{ }^{13} \mathrm{C} \mathrm{NMR}\left(\mathrm{CDCl}_{3} ; 75 \mathrm{MHz}\right) \delta \mathrm{ppm}: 182.18$ $(\mathrm{C}=\mathrm{O}) ; 161.82(\mathrm{~N}-\mathrm{C}=\mathrm{O}) ; 148.46,144.22,132.35,114.97(\mathrm{Cq})$; 135.53, 131.51, $123.24\left(\mathrm{CH}_{\mathrm{Ar}}\right) ; 130.57(\mathrm{CH}) ; 52.43,45.85,38.43$, $30.38,30.16,29.11,28.26,23.38\left(\mathrm{CH}_{2}\right) ; 18.50\left(\mathrm{CH}_{3}\right)$. 6:5-chloro-1-((1-dodecyl-1H-1,2,3-triazol-4-yl)methyl)indoline2,3-dione:

Yield: $70 \%$; $\mathrm{mp}: \quad 135-138^{\circ} \mathrm{C} ; \quad \mathrm{R}_{\mathrm{f}}=0.55 .{ }^{1} \mathrm{H} \quad \mathrm{NMR} \quad\left(\mathrm{CDCl}_{3}\right.$ $300 \mathrm{MHz}) \delta$ ppm 7.52(m, H, $\left.\mathrm{H}_{\mathrm{Ar}}\right) ; 7.47-7.50\left(\mathrm{~m}, 2 \mathrm{H}, \mathrm{H}_{\mathrm{Ar}}\right) ; 7.28(\mathrm{~d}$, $\left.\mathrm{H}, \mathrm{H}_{\mathrm{Ar}},{ }^{4} \mathrm{~J}_{\mathrm{H}-\mathrm{H}}=3 \mathrm{~Hz}\right) ; 4.94\left(\mathrm{~s}, 2 \mathrm{H}, \mathrm{CH}_{2}\right) ; 4.24\left(\mathrm{t}, 2 \mathrm{H}, \mathrm{CH}_{2},{ }^{4} \mathrm{~J}_{\mathrm{H}-\mathrm{H}}\right.$ $=3 \mathrm{~Hz}) ; 1.80\left(\mathrm{t}, 2 \mathrm{H}, \mathrm{CH}_{2},{ }^{3} \mathrm{~J}_{\mathrm{H}-\mathrm{H}}=9 \mathrm{~Hz}\right) ; 1.17\left(\mathrm{~m}, 18 \mathrm{H}, \mathrm{CH}_{2}\right) ; 0.79$ $\left(\mathrm{t}, 3 \mathrm{H}, \mathrm{CH}_{3},{ }^{3} \mathrm{~J}_{\mathrm{H}-\mathrm{H}}=6 \mathrm{~Hz}\right) .{ }^{13} \mathrm{C} \mathrm{NMR}\left(\mathrm{CDCl}_{3} ; 75 \mathrm{MHz}\right) \delta \mathrm{ppm}$ : $181.64(\mathrm{C}=\mathrm{O}) ; 161.29(\mathrm{~N}-\mathrm{C}=\mathrm{O}) ; 147.93,143.69,114.44(\mathrm{Cq})$; 135.00, 130.97, $122.71\left(\mathrm{CH}_{\mathrm{Ar}}\right) ; 123.34(\mathrm{CH}) ; 51.89,45.32,37.90$, 29.84, 29.63, 28.58, 27.72, $22.85\left(\mathrm{CH}_{2}\right) ; 17.97\left(\mathrm{CH}_{3}\right)$.

\section{Conclusion}

Some interesting 1.2.3-triazoles derivatives of 5-Chloroisatin were synthesized and confirmed by NMR elemental analysis. A systematic theoretical study on the regioselectivity in the intramolecular 1,3-dipolar cycloaddition reactions using B3LYP/631G/DFT method was conducted. Reaction course may be interpreted on the basis of nucleophile-electrophile of the dipole and the dipolarophile. In addition, we have found that the studied reactions take place with a complete regioselectivity yielding, in all cases; they are in clear agreement with the experimental data. Analysis of the global stability indices allows predicting that the most stable regioisomer shows the best yield.

\section{Acknowledgement}

The authors would like to thank all the people who helped to carry out this work such as ${ }^{1} \mathrm{H}$ NMR, ${ }^{13} \mathrm{C}$ NMR.

\section{References}

[1] Tribak, Z.; El Amin, O.; Skalli, M.K.; Senhaji, O. ;Kandri. Rodi, Y.; Houssaini. Iraqui, M.; Synthesis, Characterization, and Antibacterial Activity of Some Novel 5-Chloroisatin Derivatives. Int. J. Eng. Res. Appl. 2017, 7(6), 66-70.

[2] Foss, Jr. F W.; Mathews, T P. ; Kharel, Y ; Kennedy, P C. ; Snyder, A H. ; Davis M D. ; Lynch, K R. ; Macdonald, T L.; Synthesis and Biological Evaluation of Sphingosine Kinase Substrates as Sphingosine-1-Phosphate Receptor Prodrugs. Bioorg Med Chem. 2009; 17(16): 6123-6136.https://doi.org/10.1016/j.bmc.2009.04.015.

[3] Fowler, P W.,' Manolopoulos, D E.; Ryan, R P.; Isomerisations of the fullerenes. Carbon. 1992, 30, 12351250.https://doi.org/10.1016/0008-6223(92)90065-5.

[4] Prato. M.; Fullerene chemistry for materials science applications. J. $\begin{array}{llll}\text { Mater. } & \text { Chem., } & 1997, & 7,\end{array}$ 1109.https://doi.org/10.1039/a700080d.

[5] Moriyama, S.; Vallée, Y.; Thermal Isomerization of 1,3-Dipolar Cycloadducts of 3,4-Dihydro- $\beta$-carboline 2-Oxide. Eur. J. Org. Chem. 1998, 7, 1391-1395.https://doi.org/10.1002/(SICI)10990690(199807)1998:7<1391::AID-EJOC1391>3.0.CO;2-G.

[6] Wannassi, N. ; Rammah, M M.; Rammah, M B.; Ciamala, K. Synthese des spirocyclopropanes via la cycloaddition dipolaire-1,3 du diazoacetated'ethyle avec les arylidenes d'indan-1',3'-dione. Journal de la SociétéChimique de Tunisie, 2012, 14, 117-125.

[7] Kumar Kaushik, N.; Kaushik, N.; Attri, P.; Kumar, N.; Hyeok Kim, C .; Kumar Verma, A.; Ha Choi, E.; Biomedical Importance of Indoles. Molecules. 2013, 18 (6), 66206662.https://doi.org/10.3390/molecules 18066620 .

[8] Krug, M.; Hilgeroth, A.; Recent advances in the development of multi-kinase inhibitors.Mini-Rev. Med. Chem. 2008, 8, 1312 1327.https://doi.org/10.2174/138955708786369591.
[9] Tribak, Z.; Ghibate, R.; Skalli, M.K.; KandriRodi, Y.; Mrani, D.; Aouniti, A.; Hammouti, B.; Senhaji, O.; Synthesis and Characterization of a New Cationic Surfactant Derived from 5-Chloro-1Hindole-2,3-dione In Aqueous Systems, Int. J. Eng Res Appl. 2017, 7 (4), 04-08.

[10] Tribak, Z.; Haoudi, A.; KandriRodi, Y.; Elmsellem, H.; Skalli, M. K.; Ouzidan, Y.; Mazzah, A.; Essassi, E.M.; Synthesis and reactivity of new heterocyclic systems derived from 5-chloro-1H-indole-2, 3-dione. Mor. J. Chem. 2016, 4(4), 1157-1163.

[11] Tribak, Z.; Haoudi, A.; Skalli, M.K.; KandriRodi, Y.; El Azzouzi, M.; Aouniti, A.; Hammouti, B. Senhaji, O. 5-Chloro-1H-indole2,3-dione derivative as corrosion inhibitor for mild steel in $1 \mathrm{M}$ H3PO4: weight loss, electrochemical and SEM studies. J. Mater. Environ. Sci. 2017, 8 (1) 298-309.

[12] Rauk, A.; Orbital Interaction Theory of Organic Chemistry, WileyInterscience, New York, 2001.

[13] Nguen, L. T.; De Proft F.; Dao V. L. ;Nguen M. T. ; Geerlings. P, A.; Theoretical approach to the regioselectivity in 1,3-dipolar cycloadditions of diazoalkanes, hydrazoic acid and nitrous oxide to acetylenes, phosphaalkynes and cyanides.J. Phys. Org. Chem., 2003, 16, 615 -625.https://doi.org/10.1002/poc.653.

[14] Geerlings, P.; De Proft, F.; Langenaeker, W.; Conceptual Density Functional Theory .Chem. Rev. 2003, 103, 1793 1874.https://doi.org/10.1021/cr990029p.

[15] Senhaji, O.; Taouil, R.; Skalli, M. K.; Bouachrine, M.; Hammouti, B.; Hamidi, M.; Al-Deyab, S.S.; Experimental and Theoretical Study for Corrosion Inhibition in Normal Hydrochloric Acid Solution by Some New Phophonated Compounds. Int. J. Electrochem. Sci., 2011, 6, 6290 - 6299.

[16] Kolb H. C.; Finn M. G; Sharpless K. R.; Click Chemistry: Diverse Chemical Function from a Few Good Reactions.Angew. Chem. Int .Ed. 2001， 40, 2004- 2021.https://doi.org/10.1002/15213773(20010601)40:11<2004::AID-ANIE2004>3.0.CO;2-5.

[17] Brase, S.; Gil, C.; Knepper, K.; Zimmermann, V.; OrganicAzides: An Exploding Diversity of a Unique Class of Compounds. Angew. Chem. Int. Ed., 2005, 44, 51885240.https://doi.org/10.1002/anie.200400657.

[18] Tribak, Z.; Haoudi, A.; KandriRodi, Y.; Elmsellem, H.; Skalli, M. K.; Ouzidan, Y.; Mazzah, A.; Essassi, E.M.; Synthesis and reactivity of new heterocyclic systems derived from 5-chloro-1H-indole2,3-dione. Mor. J. Chem. 2016, 4(4), 1157-1163.

[19] Huisgen, R.; in 1,3-Dipolar Cycloaddilion Chemistry, A. Padwa Ed., Wiley, New York, 1984.

[20] Hiberty, R Introduction à la chimiequantique, Editions de l'écolepolytechnique de Paris (2004) 203.

[21] Houk, K. N.; Sims, J.; Duke, R. E.; Strozier, R. W.; George, J. K.; Frontier molecular orbitals of 1,3 dipoles and dipolarophiles .J. Am. Chem. Soc., 1973, 95, 72877301.https://doi.org/10.1021/ja00803a017.

[22] Tribak, Zineb.; KandriRodi, Youssef.; Haoudi, Amal.; Essassi, El Mokhtar.; Capet Frédéric.; Zouihri, Hafid 1-Benzyl-5chloroindoline-2,3-dione. IUCrData. 2016, 1(6) 1, x160854

[23] Fukui, K.; Theory of orientation and stereoselection, SpringerVerlag, Berlin, 1975; .Klopman, G.; Chemical Reactivity and Reaction Paths, Wiley, New York, 1974.

[24] Weinberg, J.; Lerner, D. A.; Theoretical Study of 5-HTP. Potential New Drug Resulting from the Complexation of 5-HTP with ATP. Computational Chem, 2013, 1, 14.https://doi.org/10.4236/cc.2013.11001.

[25] Pal, S.; Chandrakumar, K. R. S.; Critical Study of Local Reactivity Descriptors for Weak Interactions: Qualitative and Quantitative Analysis of Adsorption of Molecules in the Zeolite Lattice. J. Am. Chem. $\quad$ Soc., $\quad 2000, \quad 122, \quad 4145$ 4153.https://doi.org/10.1021/ja993617t

[26] Mendez, F.; Gazquez, J. L.; Chemical Reactivity of Enolate Ions: The Local Hard and Soft Acids and Bases Principle Viewpoint. J. Am. Chem. Soc. 1994, 116, 92989301.https://doi.org/10.1021/ja00099a055.

[27] Gazquez, J. L.; Mendez, F.; the Hard and Soft Acids and Bases Principle: An Atoms in Molecules Viewpoint J. Phys. Chem., 1994, 98, 4591-4593.https://doi.org/10.1021/j100068a018.

[28] Mendez, F.; Tamariz, J.; Geerlings. P.; 1, 3-Dipolar Cycloaddition Reactions: A DFT and HSAB Principle Theoretical Model. J. Phys. Chem., (A) 102 (1998), 6292-6296.

[29] Domingo, L. R.; Picher, M. T.; A DFT study of the Huisgen 1,3dipolar cycloaddition between hindered thiocarbonylylides and tetracyanoethylene Tetrahedron, 2004, 60, 50535058.https://doi.org/10.1016/j.tet.2004.04.024.

[30] Roy, R. K.; Krishnamurti, S.; Geerlings, P.; Pal, S.; Local Softness and Hardness Based Reactivity Descriptors for Predicting Intra- and 
Intermolecular Reactivity Sequences: Carbonyl Compounds . J. Phys. Chem., 1998, (A) 102, 3746-3755.

[31] Roy, R. K.; De Proft, F.; Geerlings, P.; Site of Protonation in Aniline and Substituted Anilines in the Gas Phase: A Study via the Local Hard and Soft Acids and Bases Concept. J. Phys. Chem., 1998, (A) 102, 7035-7040.

[32] Pilepic, V.; Ursic, S.; Nucleophilic reactivity of the nitroso group. Fukui function DFT calculations for nitrosobenzene and 2-methyl2-nitrosopropane J. Molecular. Struct. Theochem. 2001, 538, 4149.https://doi.org/10.1016/S0166-1280(00)00642-4

[33] Al Houari, G.; Kerbal, A.; Miqueu, K.; Sotiropoulos, J-M. ; Garrigues, B. ; Benhadda, T. ; Benlarbi, N.; Safir, I.; Filali Baba, M. Synthese de nouveaux spiro [(3-methyl-3, 4-dihydro)-1(2h)naphtalenone-2:5'-(3',4'-diaryl-4',5'-dihydro)-isoxazoles] par la reaction de cycloaddition dipolaire-1,3. J. Mar.Chim..Heterocycl. 2008, 7, 16-23.

[34] Tribak, Zineb.; KandriRodi, Youssef.; Haoudi, Amal.; Essassi, El Mokhtar.; Capet Frédéric.; Zouihri, Hafid, 1-(12-Bromododecyl)-5chloroindoline-2,3-dione. IUCrData 2016, 1(6), 1, x160971.

[35] Tribak, Zineb. ; KandriRodi, Youssef. ; Haoudi, Amal.;Essassi, El Mokhtar. ; Capet Frédéric.; Zouihri, Hafid, 1-Allyl-5chloroindoline-2, 3-Dione. IUCrData. 2016, 1(6), 1, x160862. 